\title{
Metode Fuzzy ID3 Untuk Klasifikasi Status Preeklamsi Ibu Hamil
}

\author{
Yeni Kustiyahningsih ${ }^{1 *}$, Mula'ab $^{2}$, Nur Hasanah ${ }^{3}$ \\ ${ }^{1 * 2,3}$ Fakultas Teknik, Universitas Trunojoyo Madura, Bangkalan, Jawa Timur \\ E-mail: ${ }^{1 *}$ ykustiyahningsih@trunojoyo.ac.id
}

(Naskah masuk: 6 Mei 2020, direvisi: 1 Jun 2020, diterima: 22 Jun 2020)

\begin{abstract}
Abstrak
Angka Kematian Ibu (AKI) di Indonesia meningkat terus mulai tahun 2007 (SDKI 2012). Salah satu penyebab utamanya adalah penyakit hipertensi. Istilah hipertensi pada ibu hamil disebut dengan preeklamasi. Metode Fuzzy Decision Tree Iterative Dichotomiser 3 (ID3) digunakan untuk mengelompokkan penyakit preeklamsi menjadi 3 kelas yaitu normal, waspada preeklamsi ringan, dan bahaya preeklamsi berat. Pada penelitian ini terdapat 6 variabel yang digunakan yaitu tekanan darah sistolik, tekanan darah diastolik, usia ibu, usia kehamilan, protein urine, dan odema. Tujuan dari klasifikasi adalah membantu tenaga medis dalam memberikan tindakan kepada pasien (ibu hamil) agar diagnosisnya tepat sasaran dan lebih cepat dalam membantu pengambilan keputusan. Tahapan metode ID3 adalah melakukan inisialisasi nilai atribut fuzzy, perhitungan entropy, dan mencari nilai information gain. Uji coba sistem menggunakan algoritma $k$-fold cross validation serta menghitung akurasi menggunakan confusion matrix. Berdasarkan hasil uji coba, $k$-fold 5 mempunyai akurasi terbesar yaitu $98,44 \%$, presisi terbesar $96,66 \%$, dan recall terbesar $97,61 \%$.
\end{abstract}

Kata Kunci: Klasifikasi, Preeklamsi, FID3, Variabel, Akurasi.

\section{Fuzzy ID3 Method for Classification of Preeclampsia Status of Pregnant Women}

\begin{abstract}
The maternal mortality rate (MMR) in Indonesia continues to increase starting in 2007 (SDKI 2002). One of the main causes is hypertension. The term hypertension in pregnant women is called preeclampsia. The Fuzzy Decision Tree with Iterative Dichotomiser 3 (ID3) method is used to classify preeclampsia into 3 classes, normal, alert to mild preeclampsia, and danger of severe preeclampsia. There are 6 variables used, namely systolic blood pressure, diastolic blood pressure, age, gestational age, urine protein, and odema. This research was conducted with the aim of knowing the accuracy value of the preeclampsia status classification using Fuzzy ID3. The purpose of this research is to assist medical personnels in providing action to patients (pregnant women), so that the diagnosis is right on target and is faster in helping decision making. The stages of ID3 method are initializing fuzzy attribute values, entropy calculations, and finding information gain values. The system testing uses $k$-fold cross validation algorithm and calculates accuracy using confusion matrix. Based on trial results, $k$-fold 5 has the greatest accuracy, namely $98.44 \%$, the greatest precision $96.66 \%$ and the largest recall $97.61 \%$.
\end{abstract}

Keywords: Classification, Preeclampsia, FID3, Variables, Accuracy

\section{PENDAHULUAN}

Menurunkan Angka Kematian Ibu (AKI) merupakan target yang telah di tentukan oleh Millenium Development Goals (MDGs) dalam kurun waktu 1990-2015. Sustainable Development Goals (SDGs) adalah agenda baru World Health Organizazion (WHO) untuk mengurangi AKI dibawah 70/10.000 kelahiran hidup sampai tahun 2030 [1]. Pada tahun 2012 lembaga Survei Demografi dan Kesehatan Indonesia (SDKI) menacatat bahwa AKI sebesar 359 per 100.000 kelahiran hidup. Pada tahun 2007, AKI 228 per 100.000 kelahiran hidup. Jika dibanding dengan negara ASEAN, AKI Indonesia masih cukup tinggi. AKI di 
Singapura 6 per 100.000 kelahiran hidup, Brunei 33 per 100.000 kelahiran hidup, Malaysia dan Vietnam sama-sama mencapai 160 per 100.000 kelahiran hidup [2]. Rata-rata AKI di Indonesia disebabkan karena obstetri (penanganan kehamilan langsung) diantaranya adalah pendarahan $28 \%$, eklampsia (hipertensi kehamilan) 24\%, dan infeksi $11 \%$. Sedangkan penyebab obstetri tidak langsung adalah trauma $5 \%$ dan lain-lain $11 \%$ [2]. Berdasarkan data tersebut, eklampsi menduduki urutan kedua penyebab kematian ibu hamil. Eklampsia merupakan awal dari preeklamsi. Preeklamsi itu sendiri merupakan penyakit yang terjadi saat kehamilan dengan tanda-tanda hipertensi, odema, dan protein urine $[3,4]$. Kematian yang disebabkan oleh preklamsi dapat dicegah sejak dini. Penanganan yang tepat pada masa kritis yaitu sekitar masa persalinan. Untuk mengatasi masalah ini dibutuhkan suatu proses yang cepat dan akurat dalam mendiagnosis status preeklamsi. Hasil diagnosis sangat dibutuhkan untuk menjamin keselamatan ibu dan anak disaat proses dan persiapan kelahiran. Persalinan yang dapat dipilih yaitu dengan cara normal atau caesar dengan ketentuan jika hasil klasifikasi berupa normal, maka persalinan dilakukan secara normal. Sedangkan jika hasil klasifikasi berupa waspada preeklamsi atau bahaya preeklamsi, maka tindakan cepat yang dapat diambil yaitu memilih persalinan secara caesar $[5,6]$. Berdasarkan banyaknya faktor penyebab yang digunakan sebagai alternatif maka dibutuhkan metode untuk mempermudahkan proses pengklasifikasian. Salah satu teknik klasifikasi untuk pengenalan sebuah pola adalah decision tree. Algoritma yang terkenal dengan kemudahan dalam penggunaan dan mempunyai efektifitas yang tinggi yaitu decision tree [7, 8, 9]. Logika fuzzy digunakan untuk menangani fuzziness (kesamaran) dengan cara mempresentasikan nilai yang bersifat linguistik pada data seperti rendah, normal, tinggi dan sebagainya. Fuzzy lebih fleksibel sehingga dapat memberikan toleransi pada ketidakpastian [10]. Kelebihan fuzzy ini dapat meningkatkan nilai akurasi hasil klasifikasi. Tahapan-tahapan pada penelitian ini diantaranya adalah inisialisasi nilai fuzzy, perhitungan fuzzy entropy, nilai information gain, dan uji coba menggunakan algoritma $k$-fold.

Penelitian sebelumnya mengenai klasifikasi resiko bahaya preeklamsi pada kehamilan telah dilakukan dengan metode Fuzzy C-Means. Penelitian ini menghitung validitas indeks untuk menunjukkan jumlah cluster optimal pada clustering preeklamsi. Hasilnya menunjukkan bahwa jumlah cluster optimalnya tercapai pada titik c=2 dan efektifitas dari hasil uji coba sebesar 72,78\% [11]. Pada tahun 2016, penelitian tentang deteksi dini tingkat resiko ibu hamil terhadap preeklamsia menggunakan logika fuzzy memberikan hasil evaluasi akurasi sebesar 85\% [12]. Penelitian tentang penggunaan metode Fuzzy ID3 dalam proses klasifikasi dilakukan untuk data tidak seimbang, Hesitantant Fuzzy Information Gain (HFIG) diusulkan sebagai atribut baru kriteria seleksi yang dapat digunakan sebagai pengganti Fuzzy Information Gain (FIG). Penelitian berjudul "Klasifikasi Risiko Hipertensi Menggunakan Fuzzy Decision Tree Iterative Dichotomiser 3 (ID3)" [13], menggunakan Fuzzy ID3 berdasarkan faktor-faktor yang mempengaruhi penyakit hipertensi. Penelitian ini mendapatkan nilai akurasi sebesar $80 \%$. Serta penelitian tentang prediksi penyakit diabetes menggunkan ID3 $[14,15]$ yang mempunyai rata-rata akurasi $87,77 \%$ dengan beberapa tahapan seleksi yaitu Correlation based Feature Selection (CFS) dan Information gain $[16,17]$.

Keuntungan menggunakan metode ID3 adalah data pelatihan digunakan untuk membuat aturan prediksi mudah dimengerti, membangun pohon tercepat dan terpendek, mencari seluruh dataset untuk membuat seluruh pohon, menemukan leaf node sehingga memungkinkan data uji untuk dipangkas dan mengurangi jumlah tes, waktu penghitungan ID3 adalah fungsi linier produk dari nomor karakteristik dan nomor simpul [18].

Metode fuzzy ID3 sangat sesuai untuk melakukan klasifikasi dilihat dari tingginya nilai akurasi dari hasil penelitian yang telah dilakukan sebelumnya. Metode Fuzzy Decision Tree Iterative Dichotomiser 3 (ID3) pada penelitian ini digunakan untuk pengelompokan tiga kelas yaitu normal, waspada preeklamsi ringan, dan bahaya preeklamsi berat. Terdapat 6 variabel yang digunakan yaitu tekanan darah sistolik, tekanan darah diastolik, usia ibu, usia kehamilan, protein urine, dan odema. Penelitian ini dilakukan dengan tujuan mencari nilai akurasi yang paling tinggi dari klasifikasi status preeklamsi dengan menggunakan Fuzzy ID3. Aturan pada klasifikasi dengan akurasi yang paling tinggi dijadikan sebagai pedoman dalam menentukan keputusan status pasien (ibu hamil).

\section{METODOLOGI PENELITIAN}

\section{A. Analisis Sistem}

Analisis sistem merupakan tahap pembentukan model dan evaluasi nilai akurasi dari setiap skenario uji coba. Teknik pengambilan sampel secara random dengan dataset sebanyak 216 data ibu hamil untuk mewakili pupolasi. Dataset yang digunakan pada penelitian ini merupakan data pemeriksaan ibu hamil yang ada pada puskesmas Jrangoan, Kabupaten Sampang pada tahun 2017-2018. Data yang digunakan terdiri dari 216 data dengan 6 atribut yaitu tekanan darah sistolik, tekanan darah diastolik, usia ibu, usia kehamilan, protein urine, serta odema. Pada tahap pembentukan model, terdapat 5 skenario pengujian berdasarkan $k$-fold yang digunakan. Algoritma $k$-fold cross validation digunakan untuk membagi data training dan data testing menjadi 5 data training dan 5 data testing yang berbeda-beda. Perbedaan data tersebut mempengaruhi model dan rule yang terbentuk dari setiap skenario uji coba. Terbentuknya model mempengaruhi nilai akurasi, presisi, dan recall yang dites pada setiap uji coba.

\section{B. Algoritma}

\section{Proses Fuzzifikasi}

Proses fuzzifikasi yaitu mengubah data numerik menjadi derajat keanggotan fuzzy berdasarkan fungsi setiap keanggotaan dengan langkah yaitu mengambil data training, mengambil data dari setiap atribut, dan menghitung masingmasing derajat keanggotaan [19]. 
2. Algoritma pembentukan tree menggunakan Fuzzy ID3 Proses yang dilakukan dalam membangun tree [14, 15, 17] dengan algoritma ID3 pada Gambar 1 adalah sebagai berikut:

a. Fuzifikasi data training.

b. Menghitung fuzzy entropy dari seluruh data training menggunakan persamaan untuk menghitung nilai information gain setiap atribut.

c. Menghitung information gain setiap atribut. Information gain terbesar akan dijadikan root node.

d. Menentukan atribut terbaik dari nilai information gain terbesar sampai atribut terakhir sebagai cabang tree sampai ke daun tree.

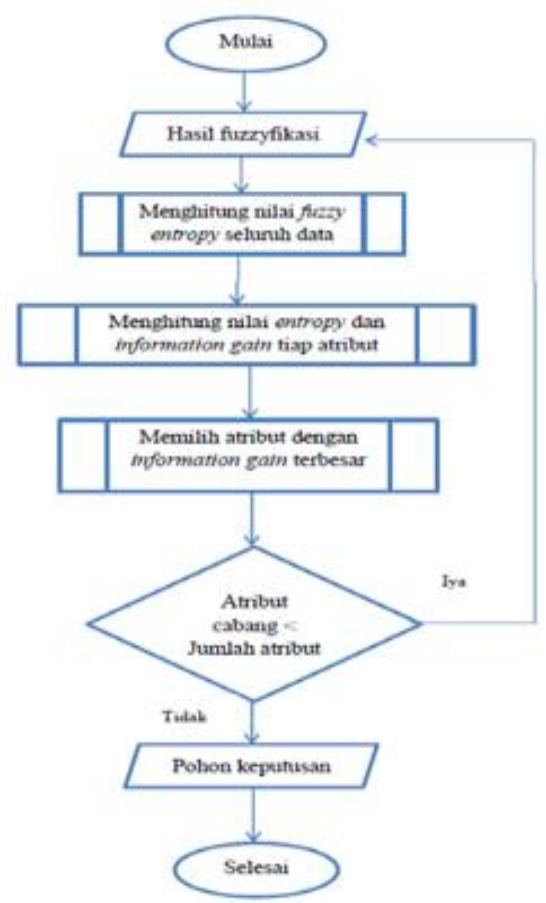

Gambar 1. Flowchart Algoritma FID3

\section{Uji Coba dan Evaluasi}

Uji coba dilakukan menggunakan algoritma $k$-fold untuk menentukan menentukan tingkat akurasi, presisi, dan recall dari sistem. Perhitungan dilakukan dengan metode confusion matrix untuk menghitung true positives, true negatives, false positives, dan false negatives untuk mendapatkan nilai akurasi dan melakukan penerapan data baru untuk menentukan hasil prediksi dan evaluasi. Langkah uji coba dan evaluasi seperti di bawah ini dan terdapat pada Gambar 2:

1. Membagi data testing dan data training menggunakan algoritma $k$-fold cros validation.

2. Membangun tree dari data training sesuai alur pada Gambar 1.

3. Melakukan uji coba menggunakan data testing dan evaluasi perhitungan akurasi, presisi, dan recall dari masing-masing fold.

4. Menerapkan rule atau tree yang memiliki akurasi tertinggi pada data baru untuk menentukan prediksi.

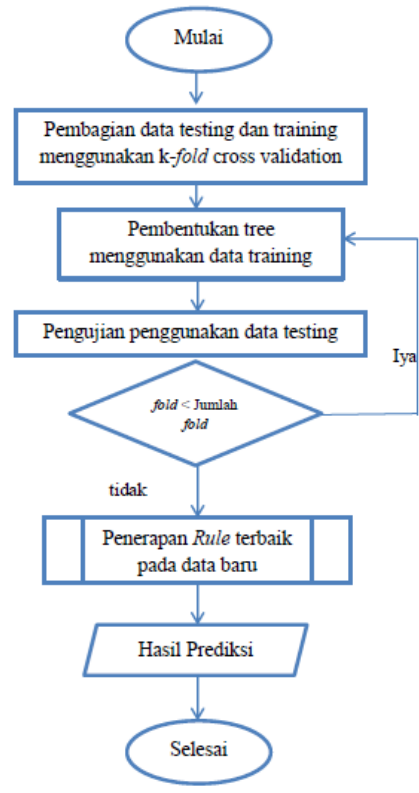

Gambar 2. Flowchart Proses Inferensi Mamdani

\section{Arsitektur Sistem}

Arsitektur sistem merupakan gambaran umum dari sistem yang dibuat sebelum program aplikasi dengan tujuan supaya aplikasi yang dibuat sesuai dengan kebutuhan sistem. Arsitektur sistem terdiri dari input, proses, dan output, seperti terlihat pada Gambar 3.

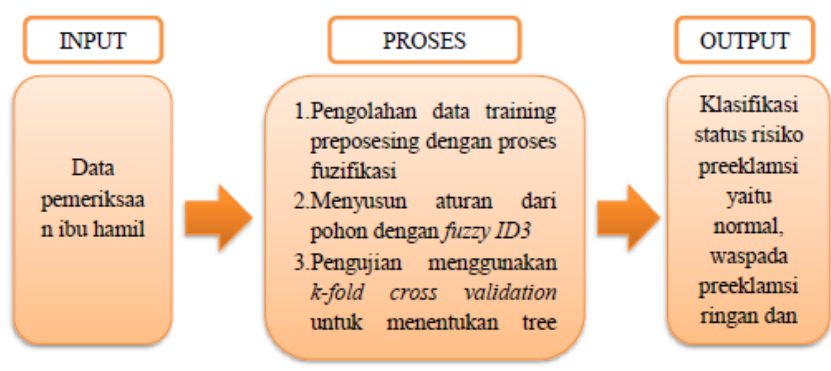

Gambar 3. Arsitektur Sistem

\section{HASIL DAN PEMBAHASAN}

A. Analisis Data

Pada bagian ini menjelaskan deskripsi data secara rinci. Dataset yang digunakan pada peneltian yaitu data pemeriksaan rutin ibu hamil beserta status preeklamsinya pada tahun 2017-2018 di puskesmas Jrangoan. Dataset berjumlah total 216 data pemeriksaan dengan 6 atribut yaitu tekanan darah sistolik (TDS), tekanan darah diastolik (TDD), umur kehamilan, umur ibu, protein urine, serta odema. Nilai rata-rata TDS pada dataset yaitu 185 , nilai rata-rata inputan atribut TDD yaitu 85 , rata-rata umur ibu 25 , rata-rata nilai inputan usia kehamilan yaitu 8,9 , serta rata-rata nilai inputan protein urine sebesar 1,5.

\section{B. Preprocessing Data (Fuzzyfikasi)}

Proses ini diawali dengan membuat fungsi nilai 
keanggotaan pada masing-masing atribut yang dipakai, dimana nilai keanggotan tertinggi menjadi nilai variabel linguistik. Pada penelitian ini digunakan range nilai setiap atribut berdasar referensi atau saran langsung para ahli.

Berikut contoh proses transformasi data pada atribut TDS. Tekanan Darah Sistolik (TDS) terdiri dari 3 himpunan fuzzy yaitu normal, tinggi, dan sangat tinggi. Kisaran TDS normal yaitu <120mmHg, TDS tinggi (stage 1) 140-159 $\mathrm{mmHg}$, sementara TDS sangat tinggi (stage 2) $>160 \mathrm{mmHg}$ [2]. Fungsi keanggotaan dari variabel TDS ditunjukkan pada Gambar 4 dan Tabel 1.

Tabel 1. Fuzzy Sets Tekanan Darah Sistolik

\begin{tabular}{ll}
\multicolumn{1}{c}{ Fuzzy Set } & \multicolumn{1}{c}{ Range } \\
\hline Normal & $\mathrm{x} \leq 140$ \\
\hline Tinggi & $140<\mathrm{x}<180$ \\
\hline Sangat Tinggi & $\mathrm{x} \geq 180$ \\
\hline
\end{tabular}

\begin{tabular}{|c|c|c|}
\hline$\mu \mathrm{TDSNormal}=$ & $\begin{array}{l}1 \\
(160-\mathrm{x}) /(160-120) \\
0\end{array}$ & $\begin{array}{l}x \leq 120 \\
120<x<160 \\
x \geq 160\end{array}$ \\
\hline$\mu$ TDSTinggi $=$ & $\begin{array}{l}0 \\
(\mathrm{x}-120) /(160-120) \\
1 \\
(200-\mathrm{x}) /(200-160) \\
0\end{array}$ & $\begin{array}{l}x \leq 120 \\
120<x<160 \\
x=160 \\
160<x<200 \\
x \geq 200\end{array}$ \\
\hline$\mu$ TDSSangat Tinggi $=$ & $\begin{array}{l}0 \\
(x-200) /(200-160) \\
1\end{array}$ & $\begin{array}{l}x \leq 160 \\
160<x<200 \\
x \geq 200\end{array}$ \\
\hline
\end{tabular}

Gambar 4. Fungsi Keanggotaan Atribut TDS

Jika ada data TDS bernilai 150 maka nilai keanggotaan fuzzy yaitu normal sebesar 0,75 , tinggi sebesar 0,25 , dan sangat tinggi sebesar 0 . Nilai linguistik terbesar dari TDS adalah normal.

\section{Pembentukan Model}

Pada proses ini, kumpulan data (dataset) yang sudah ditransformasikan dalam bentuk fuzzy diproses menggunakan algoritma $k$-fold cross validation. Dimana algoritma ini digunakan menentukan atau membagi dataset fuzzy menjadi data training dan data testing sesuai dengan jumlah fold yang digunakan. Pada umumnya $k$-fold crossvalidation menggunakan $\mathrm{k}=5$ atau $\mathrm{k}=10$ tergantung jumlah sampel yang ditunjukkan untuk menghasilkan tingkat kesalahan uji coba [17].

\section{Uji Coba Sistem}

Uji coba pada penelitian ini dilakukan dengan jumlah dataset sebanyak 216 records dan menggunakan fold 1-5, sehingga dataset yang dibagi menjadi 5 bagian, masingmasing bagian terdapat 43 records. Sesuai dengan algoritma $k$-fold cross validation dimana data terbentuk D1, D2, D3,... $\mathrm{Dt}, \mathrm{t}=1,2,3,4,5$ dengan perbandingan $20 \%$ pertama sebagai data testing (43 records) dan $80 \%$ sisa menjadi data training (173 records) dan seterusnya seperti terdapat pada Gambar 5.

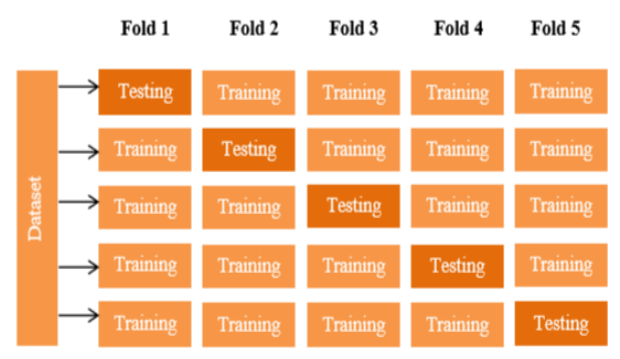

Gambar 5. Pembagian Dataset

- Uji Coba Fold-1

Data training yang terbentuk digunakan untuk memodelkan aloritma fuzzy ID3 dalam proses klasifikasi. Data training fold ke-1 dengan jumlah 173 records diterapkan pada algoritma fuzzy ID3 untuk mendapatkan model dan aturan klasifikasi. Menghitung entropy dan information gain dari training set yang sudah di fuzzyfikasi merupakan proses pembentukan aturan klasifikasi. Hasil perhitungan dapat dilihat pada Tabel 2.

Tabel 2. Daftar Nilai Entropy dan Information Gain Fold-1

\begin{tabular}{lr}
\hline \multicolumn{1}{c}{ Nilai } & \multicolumn{1}{c}{ Hasil } \\
\hline Fuzzy Entropy & 1,57095 \\
\hline IG TDS & 0,6601 \\
\hline IG TDD & 0,59059 \\
\hline IG Umur Ibu & 0,1916 \\
\hline IG Usia Kehamilan & 0,4464 \\
\hline IG Protein Urine & 1,3442 \\
\hline IG Odema & 0,2223 \\
\hline
\end{tabular}

- Uji Coba Fold-2

Hasil perhitungan entropy dan information gain dari training set skenario 2 dapat dilihat pada Tabel 3.

Tabel 3. Daftar Nilai Entropy dan Information Gain Fold-2

\begin{tabular}{lr}
\hline \multicolumn{1}{c}{ Nilai } & \multicolumn{1}{c}{ Hasil } \\
\hline Fuzzy Entropy & 1,57095 \\
\hline IG TDS & 0,5601 \\
\hline IG TDD & 0,59059 \\
\hline IG Umur Ibu & 0,1916 \\
\hline IG Usia Kehamilan & 0,4464 \\
\hline IG Protein Urine & 1,3442 \\
\hline IG Odema & 0,2223 \\
\hline
\end{tabular}

\section{- Uji Coba Fold-3}

Hasil perhitungan entropy dan information gain dari training set skenario 3 dapat dilihat pada Tabel 4.

Tabel 4. Daftar Nilai Entropy dan Information Gain Fold-3

\begin{tabular}{lr}
\multicolumn{1}{c}{ Nilai } & \multicolumn{1}{c}{ Hasil } \\
\hline Fuzzy Entropy & 1,57095 \\
\hline IG TDS & 0,5601 \\
\hline IG TDD & 0,59059 \\
\hline IG Umur Ibu & 0,2334 \\
\hline IG Usia Kehamilan & 0,4464 \\
\hline IG Protein Urine & 0,8222 \\
\hline IG Odema & 0,2723 \\
\hline
\end{tabular}


- Uji Coba Fold-4

Hasil perhitungan entropy dan information gain dari training set skenario 4 dapat dilihat pada Tabel 5.

Tabel 5. Daftar Nilai Entropy dan Information Gain Fold-4

\begin{tabular}{lc}
\hline \multicolumn{1}{c}{ Nilai } & Hasil \\
\hline Fuzzy Entropy & 1,57095 \\
\hline IG TDS & 0,5601 \\
\hline IG TDD & 0,59059 \\
\hline IG Umur Ibu & 0,1916 \\
\hline IG Usia Kehamilan & 0,4464 \\
\hline IG Protein Urine & 1,3442 \\
\hline IG Odema & 0,2223 \\
\hline
\end{tabular}

\section{- Uji Coba Fold-5}

Hasil perhitungan entropy dan information gain dari training set skenario 5 dapat dilihat pada Tabel 6. Daftar nilai entropy dan information gain model tree yang terbentuk dapat dilihat pada Gambar 6.

Tabel 6. Daftar Nilai Entropy dan Information Gain Fold-5

\begin{tabular}{lc}
\multicolumn{1}{c}{ Nilai } & Hasil \\
\hline Fuzzy Entropy & 1,66095 \\
\hline IG TDS & 0,7601 \\
\hline IG TDD & 0,5759 \\
\hline IG Umur Ibu & 0,2998 \\
\hline IG Usia Kehamilan & 0,4464 \\
\hline IG Protein urine & 0,9442 \\
\hline IG Odema & 0,2523 \\
\hline
\end{tabular}

Aturan yang diperoleh dengan menghubungkan setiap node yang dilewati sejak dari root node sampai leaf node. Hasil aturan dari model tree adalah 17 aturan dibawah ini:

1. Jika protein urine normal dan TDS normal dan odema ya, maka waspada preeklamsi ringan.

2. Jika protein urine normal dan TDS normal dan odema tidak, maka normal.
3. Jika protein urine normal dan TDS sangat tinggi, maka bahaya preeklamsi berat.

4. Jika protein urine normal dan TDS tinggi, maka waspada preeklamsi ringan.

5. Jika protein urine sangat tinggi dan TDS normal dan odema ya, maka bahaya preeklamsi berat.

6. Jika protein urine sangat tinggi dan TDS normal dan odema tidak dan TDD normal dan umur ibu tinggi dan usia kehamilan trimester 3, maka waspada preeklamsi ringan.

7. Jika protein urine sangat tinggi dan TDS normal dan odema tidak dan TDD tinggi, maka waspada preeklamsi ringan.

8. Jika protein urine sangat tinggi dan TDS sangat tinggi, maka bahaya preeklamsi berat.

9. Jika protein urine sangat tinggi dan TDS tinggi, maka bahaya preeklamsi berat.

10.Jika protein urine tinggi dan TDS normal dan TDD normal, maka waspada preeklamsi ringan.

11. Jika protein urine tinggi dan TDS normal dan TDD tinggi dan umur ibu tinggi dan usia kehamilan trimester 2 dan odema ya, maka waspada preeklamsi ringan.

12. Jika protein urine tinggi dan TDS sangat tinggi, maka bahaya preeklamsi berat.

13. Jika protein urine tinggi dan TDS tinggi dan umur ibu sangat tinggi dan TDD normal, maka waspada preeklamsi ringan.

14. Jika protein urine tinggi dan TDS tinggi dan umur ibu sangat tinggi dan TDD tinggi dan odema ya dan usia kehamilan trimester, maka waspada preeklamsi ringan.

15.Jika protein urine tinggi dan TDS tinggi dan umur ibu sangat tinggi dan TDD tinggi dan odema tidak dan usia kehamilan trimester, maka waspada preeklamsi ringan.

16. Jika protein urine tinggi dan TDS tinggi dan umur ibu tinggi dan TDD normal dan usia kehamilan trimester 3 dan odema tidak, maka waspada preeklamsi ringan.

17. Jika protein urine tinggi dan TDS tinggi dan umur ibu tinggi dan TDD tinggi, dan usia kehamilan trimester 3 dan odema tidak, maka waspada preeklamsi ringan.

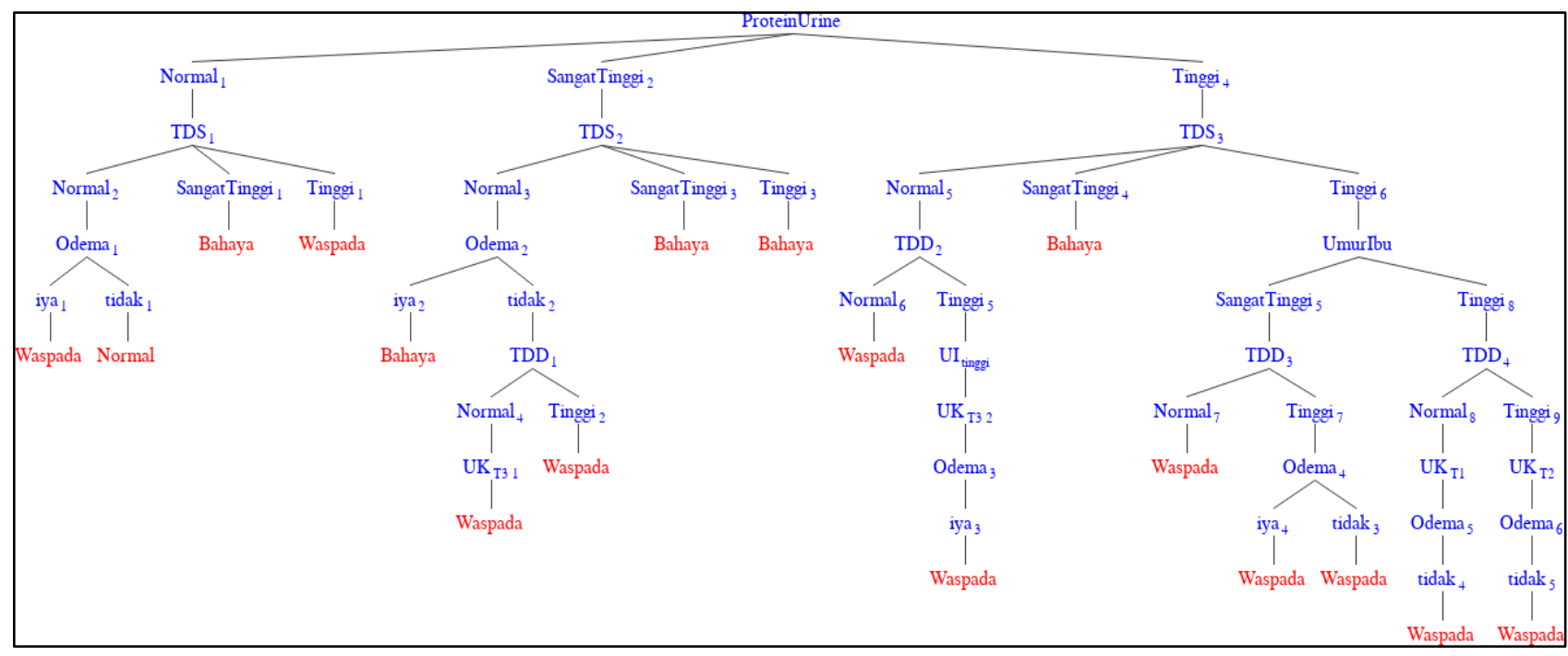

Gambar 6. Model Tree yang Terbentuk Dari $K$-fold 5 
E. Analisis Metode

Pada tahap analisis nilai akurasi hasil dari proses testing akan dihitung nilai akurasi, presisi, dan recall menggunakan metode confusion matrix, dimana kita akan mencari nilai true positives (TP), false positives (FP), false negatives $(\mathrm{FN})$ dan true negatives (TN) di setiap skenario testing. Sebagai contoh perhitungan akurasi pada fold-1 seperti di bawah ini:

1. Presisi $=21 /(21+1)=94,1176$

2. Recall $=21 /(21+2)=92,8571$

3. Akurasi $=(21+28) /(21+28+1+2)=95,4545$

Hasil evaluasi dari masing-masing skenario testing dapat dilihat pada Tabel 7 di bawah ini.

Tabel 7. Nilai Akurasi, Presisi, dan Recall

\begin{tabular}{crrr}
\hline Fold ke- & Akurasi (\%) & Presisi (\%) & \multicolumn{1}{c}{ Recall(\%) } \\
\hline 1 & 95,45 & 94,12 & 92,86 \\
\hline 2 & 92,25 & 90,74 & 90,19 \\
\hline 3 & 92,25 & 89,13 & 89,52 \\
\hline 4 & 93,79 & 91,41 & 90,22 \\
\hline 5 & 98,45 & 96,67 & 97,62 \\
\hline
\end{tabular}

Berdasar tabel evaluasi Tabel 6 dapat dilihat bahwa nilai akurasi tertinggi tedapat pada uji coba fold ke-5 yaitu sebesar $98,45 \%$. Hal ini menunjukkan model dan aturan klasifikasi dari fold ke-5 dengan 17 aturan dan menjadi aturan klasifikasi dari data testing baru yang akan diinputkan. Data testing juga mengalami proses fuzzyfikasi sebelum diuji menggunakan rule, transformasinya dapat dilihat pada Tabel 8 dan Tabel 9.

Tabel 8. Data Testing

\begin{tabular}{l|c|r|rrrr}
\hline TDS & TDD & Umur Ibu & $\begin{array}{c}\text { Usia } \\
\text { Kehamilan }\end{array}$ & $\begin{array}{c}\text { Protein } \\
\text { Urine }\end{array}$ & Odema \\
\hline 120 & 80 & 22 & 6,5 & 0 & Tidak \\
\hline 140 & 90 & 39 & 8 & $1+$ & Ya \\
\hline 200 & 90 & 18 & 9 & $2+$ & Ya \\
\hline
\end{tabular}

Tabel 9. Hasil Fuzzyfikasi dan Prediksi

\begin{tabular}{lllllll}
\hline TDS & TDD & $\begin{array}{c}\text { Umur } \\
\text { Ibu }\end{array}$ & $\begin{array}{c}\text { Usia } \\
\text { Hamil }\end{array}$ & $\begin{array}{c}\text { Protein } \\
\text { Urine }\end{array}$ & $\begin{array}{c}\text { Ode } \\
\text { ma }\end{array}$ & $\begin{array}{c}\text { Hasil } \\
\text { Prediksi }\end{array}$ \\
\hline Normal & Normal Tinggi & $\begin{array}{l}\text { Trimester } \\
2\end{array}$ & Normal & Tidak Normal \\
\hline Normal & Normal $\begin{array}{l}\text { Sangat } \\
\text { Tinggi }\end{array}$ & $\begin{array}{l}\text { Trimester } \\
\text { Tinggi }\end{array}$ & Ya & $\begin{array}{l}\text { Waspada } \\
\text { preeklamsi } \\
\text { berat }\end{array}$ \\
\hline $\begin{array}{l}\text { Sangat } \\
\text { Tinggi }\end{array}$ & Normal Tinggi & $\begin{array}{l}\text { Trimester } \\
3\end{array}$ & Sangat & Tinggi & Ya & $\begin{array}{l}\text { Bahaya } \\
\text { preeklamsi } \\
\text { ringan }\end{array}$ \\
\hline
\end{tabular}

\section{KESIMPULAN}

Kesimpulan dari penelitian ini adalah bahwa algoritma Fuzzy ID3 dapat diterapkan dalam proses klasifikasi status preeklamsi pada ibu hamil berdasar atribut tekanan darah sistolik, tekanan darah diastolik, usia ibu, usia kehamilan, protein urine, dan odema. Atribut yang menjadi root atau akar dari pohon keputusan dalam penelitian ini adalah protein urine, sebagai parameter penentu utama yang ditentukan untuk klasifikasi status preeklamsi ibu hamil. Berdasarkan hasil uji coba, $k$-fold 5 mempunyai hasil akurasi yang tertinggi yaitu $98,44 \%$, presisi terbesar $96,66 \%$, dan recall terbesar $97,61 \%$ dengan 17 aturan, sehingga menjadi aturan terbaik yang dapat digunakan untuk klasifikasi status preeklamsi ibu hamil. $K$-fold 5 dengan aturan 4 fold sebagai data training dan 1 fold sebagai data testing, mempunyai data training yang paling banyak dibanding $k$-fold 1 sampai $k$-fold 4. Hal ini menunjukkan bahwa semakin besar data training, maka semakin tinggi akurasi klasifikasi. Penelitian ini dapat dikembangkan dengan melakukan proses pemangkasan pohon (pruning) pada tree yang terbentuk. Pruning dapat dilakukan juga menggunakan pre pruning dan post pruning untuk menentukan akurasi yang terbaik.

\section{REFERENSI}

[1] Jayanti, K., Dwi, B.N., Hari, Wibowo A. (2016). Faktor yang Mempengaruhi Kematian Ibu. Jurnal Wiyata, Vol. 3, pp. 46-53.

[2] Badan Kependudukan dan Keluarga Berencana Nasional, Badan Pusat Statistik, Kementrian Kesehatan. (2013). Survei Demografi dan Kesehatan Indonesia. Jakarta: Kementerian Kesehatan.

[3] Wiknjosastro, H., Saifuddin, A.B., \& Rachimhadhi, T. (2005). Ilmu Kebidanan. Jakarta: Yayasan Bina Pustaka Sarwono Prawirohardjo.

[4] Winyojarwo, H. (2006) Ilmu Kebidanan, Indonesia: Yayasan Bina Pustaka Sarwo Prawiroharjo.

[5] Faiqoh, E. \& Hendrati, L.Y. (2014) Hubungan Karakteristik Ibu, dan Kepatuhan. Jurnal Berkala Epidemiologi, Vol. 2(2), pp. 216-226.

[6] Kementrian Kesehatan Republik Indonesia. (2013). Buku Saku Pelayan Kesehatan Ibu di Fasilitas Kesehatan Dasar dan Rujukan. Jakarta: Kementrian Kesehatan Republik Indonesia.

[7] Yunita, P., Umi, S. \& Ristu, S. (2013). Klasifikasi Risiko Bahaya Kehamilan dengan Metode Fuzzy CMeans. ITSMART, Vol. 2(1), pp. 8-15.

[8] Kusumadewi, S. \& Purnomo, H., (2010). Aplikasi Logika Fuzzy untuk Pendukung Keputusan. Yogyakarta: Graha Ilmu.

[9] Nugraheni, A.M., (2016). Sistem Pakar Deteksi Dini Tingkat Resiko Pada Ibu Hamil Terhadap Preeklamsi Dengan Logika Fuzzy [Skripsi]. Surabaya.

[10] Negnevitsky, M. (2005). Artificial Intelligence: A Guide to Intelligent Systems. Pearson Education.

[11] Sardari, S., Eftekhari M. \& Fatemeh A., (2017). 
Hesitant Fuzzy Decision Tree Approach for Highly. Applied Soft Computing Jurnal, Vol. IV(21).

[12] Andriansyah, M., Rafli, Santoso, E., \& Sutrisno. (2018). Klasifikasi Risiko Hipertensi Menggunakan Fuzzy Decision Tree Iterative. Jurnal Pengembangan Teknologi Informasi dan Ilmu Komputer (JPTIIK), Vol 2(12).

[13] Efendi M. H., \& Arif. (2018). Prediksi Penyakit Diabetes Menggunakan Algoritma. Jurnal Informatika JUITA, Vol.6(1).

[14] Liang, G. (2005). A Comparative Study of Three Decision Tree Algorithms: ID3, Fuzzy ID3 and Probabilistic Fuzzy ID3 [Skripsi].

[15] Wei, Z., Xuan, Z. \& Junjie, C., (2013). Study on Classification Rules of Hypertension Based on Decision Tree. Beijing: IEEE.
[16] James, G., (2013). An Introduction to Statistical Learning: with Applications in $R$ (Springer Texts in Statistics), Springer.

[17] Kustiyahningsih, Y. \&Rahmanita E., (2016). Aplikasi Sistem Pendukung Keputusan Menggunakan Algoritma C4.5. Untuk Penjurusan SMA. Jurnal Simantec, 5(2), pp. 101-108.

[18] Bhumika G., Aditya R., Akshay J., Arpit A. \& Naresh D., (2017). Analysis of Various Decision Tree Algorithms for Classification in Data Mining. International Journal of Computer Applications, Vol. 163(8).

[19] Kustiyahningsih Y., Fatmawati, Suprajitno H., (2018). MCGDM with AHP based on Adaptive interval Value Fuzzy. Telecommunication, Computing, Electronics and Control, TELKOMNIKA, Vol. 16(1), pp. 314-322. 